\title{
Activity of four entomopathogenic nematode species against different developmental stages of Colorado potato beetle, Leptinotarsa decemlineata (Coleoptera, Chrysomelidae)
}

\author{
S. TRDAN ${ }^{1 *}$, M. VIDRIH ${ }^{1}$, L. ANDJUS ${ }^{2}, \breve{Z}$. LAZNIK $^{1}$ \\ ${ }^{1}$ University of Ljubljana, Biotechnical Faculty, Dept. of Agronomy, Chair of Phytomedicine, Agricultural Engineering, \\ Crop Production, Grassland and Pasture Management, Jamnikarjeva 101, SI-1111 Ljubljana, Slovenia, \\ E-mail: stanislav.trdan@bf.uni-lj.si; ${ }^{2}$ Natural History Museum, Njegoševa 51, 11000 Belgrade, Serbia
}

\begin{abstract}
Summary
Four entomopathogenic nematode species (Steinernema feltiae, S. carpocapsae, Heterorhabditis bacteriophora, and $H$. megidis) were tested in a laboratory bioassay for the efficacy of these pathogens in controlling the larvae and adults of the Colorado potato beetle, Leptinotarsa decemlineata. The main aim of the study was to develop an efficient sustainable control method against the pest. With this we could develop a strategy of potato production with the intention of diminishing or even preventing the appearance of pest resistance to insecticides. The activity of these biological agents was assessed at three different temperatures $\left(15,20\right.$, and $\left.25^{\circ} \mathrm{C}\right)$ and three concentrations (200, 1000, and 2000 infective juveniles per individual). Mortality of three stages (young and old larvae and adults) was determined 2, 4, and 7 days after treatment. At $15{ }^{\circ} \mathrm{C}$ entomopathogenic nematodes showed the lowest efficacy against all insect stages. No significant differences in efficacy was determined at 20 and $25{ }^{\circ} \mathrm{C}$ as all nematodes caused prompt death of all stages. At all temperatures young larvae were most susceptible. However, when controlling overwintered adults for the purpose of preventing the mass appearance of Colorado potato beetle, we recommend an application of higher concentrations of S. feltiae suspension.
\end{abstract}

Key words: biological control; efficacy; laboratory conditions; Leptinotarsa decemlineata

\section{Introduction}

Almost 85 years after its introduction into Europe, the Colorado potato beetle (Leptinotarsa decemlineata Say, Coleoptera, Chrysomelidae) is still the most important potato pest in the majority of the Old Continent countries (OEPP/EPPO, 1997). Larvae and adults feed on potato leaves and hinder the normal development of the plants. The individuals of the first generation prove to be particularly damaging (Igrc-Barčić et al., 1999), because the economic threshold is much lower than for the individuals of the second generation (Zehnder et al., 1995). In some countries the intensive use of insecticides against the Colorado potato beetle has led to the appearance of pesticide resistance (Pap et al., 1997; Stanković et al., 2004). With the intention of diminishing or preventing this phenomenon, new strategies of potato production were developed in some regions that proved to be very efficient (Pruszynski \& Wegorek, 2004). Since the insect is capable of gaining resistance to both chemical and biological insecticides (Loseva et al., 2002), the development and optimization of new and environmentally acceptable ways of controling this pest is urgently needed.

Entomopathogenic nematodes (EPNs) are biological agents which have been tested on a wide range of plant pests under laboratory conditions (Shapiro \& McCoy, 2000) and in the field (Simser, 1992; Abbas et al., 2001; Susurluk, 2008). At first they were mostly known as antagonists of soil pests, but in recent years many investigations have demonstrated that they can also be effectively used against foliar pests (Arthurs et al., 2004).

In Europe, the efficacy of EPNs on the Colorado potato beetle was studied in the 1970s in Poland (Seryczynska \& Kamionek, 1974; Lipa et al., 2008). In one of the latest studies (Prishchepa et al., 2000), the efficacy of the Belarus strains of Steinernema feltiae and S. carpocapsae has been proven - and the results of other studies indicate the higher efficacy of $S$. carpocapsae in comparison with strain HP 88 from the genus Heterorhabditis (Saringer et al., 1996). A study in North America has shown that $S$. carpocapsae persists in the body of the Colorado potato beetle through both the larval-pupal and pupal-adult transitions (Stewart et al., 1998). This indicates that $S$. carpocapsae could be more useful for foliar application where the nematodes are unlikely to survive long outside a host due to their sensitivity to environmental factors. Thus, 
it is preferable that the endoparasite can enter the host at all stages and stay within the host. However, one study has shown relative inefficiency of $S$. carpocapsae in controlling the Colorado potato beetle (Thurston et al., 1994). Thus, with some studies providing positive results and others providing weaker results for the use of this entomopathogenic species, we were interested in reassessing $S$. carpocapsae in comparison to other EPN species.

In the country where this research was performed (Slovenia), only the use of $S$. feltiae and $S$. carpocapsae is now allowed, since they recently became an indigenous species (Laznik et al., 2008ab). But all preliminary research on this agent has been conducted under laboratory conditions (Trdan et al., 2006, Trdan et al., 2008). We have now investigated the ability of EPNs to infect larvae and adults of the Colorado potato beetle in a rearing chamber. The aim of this research was to determine how the factors of environmental temperature and EPN concentration, both important factors with impact on the control efficacy (Kreutz et al., 2004; Athanassiou et al., 2006) - influence the efficacy against different developmental stages of the pest.

\section{Materials and methods}

Entomopathogenic nematodes and Colorado potato beetles The laboratory investigation was carried out in the Entomological Laboratory of the Chair of Phytomedicine, Agricultural Engineering, Crop Production, Grassland and Pasture Management (University of Ljubljana, Biotechnical Faculty, Department of Agronomy) in Ljubljana, Slovenia. The following four species of EPNs were tested: Steinernema feltiae (Filipjev) and S. carpocapsae (Weiser) (both Rhabditida: Steinernematidae); and Heterorhabditis bacteriophora Poinar and H. megidis Poinar, Jackson \& Klein (both Rhabditida: Heterorhabditidae). Commercial products from Koppert B. V. (Berkel en Rodenrijs, The Netherlands) were supplied by air-mail and used within 6 weeks of their receipt. Once received, the nematode preparations were stored in the dark in a refrigerator $\left(2-4{ }^{\circ} \mathrm{C}\right)$. Before each use, the quality of the nematodes was checked. Larvae (L1/L2 and L3/L4) and adults of the Colorado potato beetle were collected on potato plants, cv. Kondor, from a test plot of the Biotechnical Faculty in Ljubljana. Adults and larvae of both generations were used for the laboratory research. Young larvae (L1/L2) were collected in the first half of June and in the first half of August and older larvae (L3/L4) in the second half of June and in the second half of August. Adults were collected in mid- July and in mid- September. Individuals were hand picked in the early afternoon, placed in plastic container, and transported to the laboratory where they were exposed to EPNs.

\section{Laboratory bioassay}

The efficacy of EPNs was tested at three concentrations: 200, 1000, and 2000 infective juveniles (IJs) per individual or 2000, 10000 and 20000 IJs in $1 \mathrm{ml}$ of water per Petri dish. The main reason for the use of relatively high concentrations of nematode suspensions is the fact, that the nematodes were also tested against the Colorado potato beetle adults. The adults are known as less susceptible to nematodes attack (Svendsen \& Steenberg, 2000), therefore higher concentrations of nematode suspensions were also used in many of previous studies on the efficacy of these biological control agents (Lacey et al., 1993; Trdan et al., 2008).

About five potato leaves were placed in each of several 14 $\mathrm{cm}$ (diameter) Petri dishes lined with filter paper disks. Ten L1/L2 Colorado potato beetle larvae were then put in each Petri dish. The same was done also with L3/L4 larvae and adult Colorado potato beetles. Suspensions of nematodes were prepared in glass jars, and each Petri dish was given $1 \mathrm{ml}$ of suspension. The Petri dishes were then closed. Suspensions were added to the potato leaves with a pipette whose tip was changed after every treatment. In this way we simulated the foliar application of the nematodes. The fifth treatment was a control with $1 \mathrm{ml}$ distilled water added to each Petri dish instead of nematode suspension. This type of testing is widely used in the field of entomopathogenic nematology, the most actively with the steinernematids (Dolinski et al., 2006), but also with heterorhabditids (Rosa \& Simões, 2004).

The Petri dishes were put in a RK-900 CH type rearing chamber provided by Kambič Laboratory equipment (Semič, Slovenia) with a working capacity of $0,868 \mathrm{~m}^{3}$ (width $\times$ height $\times$ depth $=1000 \times 1400 \times 620 \mathrm{~mm}$ ). Each treatment was done in 10 replicates. Dishes were kept in the dark at three different temperatures $\left(15,20\right.$, and $\left.25^{\circ} \mathrm{C}\right)$ at a relative humidity of $95 \%$. The number of dead individuals was determined at 2, 4, and 7 days after treatment (DAT). Because of the large quantity of the results, only the data acquired 7 DAT are presented in this paper. Offspring of Steinernema nematodes appeared inside the dead insects after 8 days, while emergence of Heterorhabditis nematodes was observed after 14 days. Nematode-caused morality of the Colorado potato beetles was thus confirmed.

\section{Statistical analysis}

A multifactor analysis of variance (ANOVA) was conducted to determine the differences in mortality (\%) between the larvae (L1/L2, L3/L4) and adults of the Colorado potato beetle. Before the analysis, each variable was tested for homogeneity of treatment variances. The mortality data were corrected according to Abbott's formula (Abbott, 1925) and normalized using the arcsine square-root transformation. Duncan's multiple range test $(P$ $\leq 0.05$ ) was used to separate mean differences among the parameters in all the treatments. $\mathrm{LC}_{50}$ and $\mathrm{LC}_{90}$ values (numbers of IJs/individual causing $50 \%$ and $90 \%$ mortality) were estimated. All statistical evaluations were performed with Statgraphics Plus for Windows 4.0 (Statistical Graphics Corp., Manugistics, Inc., Maryland, USA). Data are presented as untransformed means \pm SE. 


\section{Results}

Analysis of pooled results

The percentage mortality of the Colorado potato beetle was significantly influenced by temperature $(F=37.98$; df $=2$, $3219 ; P<0.001)$, EPN species $(F=25.47 ; \mathrm{df}=3,3219 ; P$ $<0.001)$, nematode concentration $(F=40.93$; df $=2,3219$; $P<0.001)$, DAT $(F=25.10 ; \mathrm{df}=2,3219 ; P<0.001)$, and developmental stage $(F=203.73$; df $=2,3219 ; P<0.001)$. All interactions were non-significant. In all nematode treatments, the total mortality was significantly higher than the mortality in the control treatment. Corrected mortality was therefore calculated.

The highest mortality of the Colorado potato beetle was recorded at $20{ }^{\circ} \mathrm{C}(56.79 \pm 2.54)$ and $25{ }^{\circ} \mathrm{C}(61.29 \pm 2.33)$ with $S$. feltiae $(60.07 \pm 2.08)$ and $S$. carpocapsae $(61.66 \pm$ $2.20)$ at $2000 \mathrm{IJs} /$ adult $(62.15 \pm 1.84)$ and at $7 \mathrm{DAT}(70.66$ $\pm 2.23)$. The lowest mortality was seen at $15{ }^{\circ} \mathrm{C}(36.37 \pm$ 1.57), with $H$. megidis $(41.87 \pm 1.88)$ and $H$. bacteriophora $(42.35 \pm 1.96)$, at $200 \mathrm{IJs} /$ adult $(37.13 \pm 1.54)$, and at 2 DAT (30.91 \pm 1.71$)$. Young larvae were the most susceptible developmental stage of the pest $(79.24 \pm 1.81)$, while adults showed the highest tolerance $(18.86 \pm 1.08)$ to EPNs infection.

\section{Individual analysis}

At 15 and $20{ }^{\circ} \mathrm{C}$, a significant influence of EPN species, nematode concentration, and the interaction between EPN species and nematode concentration on mortality of the young larvae was assessed seven days after treatment (Table 1). At $25^{\circ} \mathrm{C}$, the influence of both parameters and their interaction was non-significant.
In the 15 and $25^{\circ} \mathrm{C}$ conditions, significant influences were found on the mortality of old larvae seven days after treatment for EPN species, nematode concentration, and the interaction between EPN species and nematode concentration, while at $20{ }^{\circ} \mathrm{C}$ none of the parameters or their interaction had such influence.

At $15{ }^{\circ} \mathrm{C}$, a significant effect of EPN species, nematode concentration and interaction between both factors was ascertained for adult mortality seven days after treatment, while at $25{ }^{\circ} \mathrm{C}$ only significant influence for nematode concentration and the interaction between EPN species and nematode concentration was approved. Just the same as for the old larvae, at $20{ }^{\circ} \mathrm{C}$ none of the parameters or their interaction had significant influence on the adult mortality.

\section{Dose effect of EPNs}

$\mathrm{LC}_{50}$ and $\mathrm{LC}_{90}$ values calculated from the bioassay at the seventh day after treatment are summarized in Table 2. At $15{ }^{\circ} \mathrm{C}$ the lowest LC values are those of $S$. feltiae $\left(\mathrm{LC}_{50}=\right.$ $484 \mathrm{IJ}$ /young larvae and $\mathrm{LC}_{90}=1025 \mathrm{IJ}$ /old larvae). The highest values at the same temperature are attributed to $S$. carpocapsae $\left(\mathrm{LC}_{50}=2111 \mathrm{IJs} /\right.$ adult, and $\mathrm{LC}_{90}=3000$ IJs/adult). At $20{ }^{\circ} \mathrm{C}$ the lowest $\mathrm{LC}_{50}$ values are associated with $S$. carpocapsae $\left(\mathrm{LC}_{50}=463 \mathrm{IJ}\right.$ s/adult) and $H$. megidis $\left(\mathrm{LC}_{90}=664\right.$ IJs/old larvae), while the highest values belong to $H$. megidis $\left(\mathrm{LC}_{50}=1375 \mathrm{IJs} /\right.$ adult $)$ and $S$. feltiae $\left(\mathrm{LC}_{90}=1992 \mathrm{IJ}\right.$ /old larvae). At the highest temperature, $S$. carpocapsae $\left(\mathrm{LC}_{50}=541\right.$ IJs/old larvae) and $H$. bacteriophora $\left(\mathrm{LC}_{90}=1057 \mathrm{IJ} /\right.$ adult $)$ proved to be the most effective against the pest, while $S$. feltiae $\left(\mathrm{LC}_{50}=\right.$ $1250 \mathrm{IJs} /$ adult $)$ and $H$. bacteriophora $\left(\mathrm{LC}_{90}=1964 \mathrm{IJs} / \mathrm{old}\right.$ larvae) showed the lowest efficacy.

Table 1: ANOVA results for corrected mortality of different developmental stages of Colorado potato beetle at three different temperatures 7 days after treatment

\begin{tabular}{|c|c|c|c|c|c|c|c|c|c|c|}
\hline \multirow{2}{*}{ Temperature } & \multirow{2}{*}{ Source } & \multicolumn{3}{|c|}{ Young larvae } & \multicolumn{3}{|c|}{ Old larvae } & \multicolumn{3}{|c|}{ Adults } \\
\hline & & $F$ & $\mathrm{df}$ & $P$ & $F$ & $\mathrm{df}$ & $P$ & $F$ & $\mathrm{df}$ & $P$ \\
\hline \multirow{3}{*}{$15^{\circ} \mathrm{C}$} & EPN species & 22.03 & 3.44 & $<0.001^{*}$ & 7.00 & 3.44 & $<0.001^{*}$ & 101.86 & 3.44 & $<0.001^{*}$ \\
\hline & $\begin{array}{c}\text { Nematode } \\
\text { concentration }\end{array}$ & 166.58 & 2.44 & $<0.001^{*}$ & 7.33 & 2.44 & $0.016^{*}$ & 40.55 & 2.44 & $<0.001^{*}$ \\
\hline & $\begin{array}{l}\text { EPN x nematode } \\
\text { concentration }\end{array}$ & 22.03 & 6.44 & $<0.001^{*}$ & 6.15 & 6.44 & $0.021^{*}$ & 30.37 & 6.44 & $<0.001^{*}$ \\
\hline \multirow{3}{*}{$20^{\circ} \mathrm{C}$} & EPN species & 37.24 & 3.44 & $<0.001^{*}$ & 3.05 & 1.20 & 0.0962 & 2.96 & 1.20 & 0.1010 \\
\hline & $\begin{array}{c}\text { Nematode } \\
\text { concentration }\end{array}$ & 31.73 & 2.44 & $<0.001^{*}$ & 1.08 & 2.20 & 0.3576 & 1.42 & 2.20 & 0.2646 \\
\hline & $\begin{array}{l}\text { EPN x nematode } \\
\text { concentration }\end{array}$ & 21.88 & 6.44 & $<0.001^{*}$ & 0.93 & 2.20 & 0.4102 & 0.06 & 2.20 & 0.9404 \\
\hline \multirow{3}{*}{$25^{\circ} \mathrm{C}$} & EPN species & 25.21 & 3.44 & 0.0752 & 10.96 & 3.44 & $<0.001^{*}$ & 10.59 & 3.44 & $<0.001^{*}$ \\
\hline & $\begin{array}{c}\text { Nematode } \\
\text { concentration }\end{array}$ & 23.12 & 2.44 & 0.0842 & 18.98 & 2.44 & $<0.001^{*}$ & 2.39 & 2.44 & 0.1035 \\
\hline & $\begin{array}{l}\text { EPN x nematode } \\
\text { concentration }\end{array}$ & 28.21 & 6.44 & 0.0911 & 2.75 & 6.44 & $0.0234^{*}$ & 2.65 & 6.44 & $0.0279^{*}$ \\
\hline
\end{tabular}




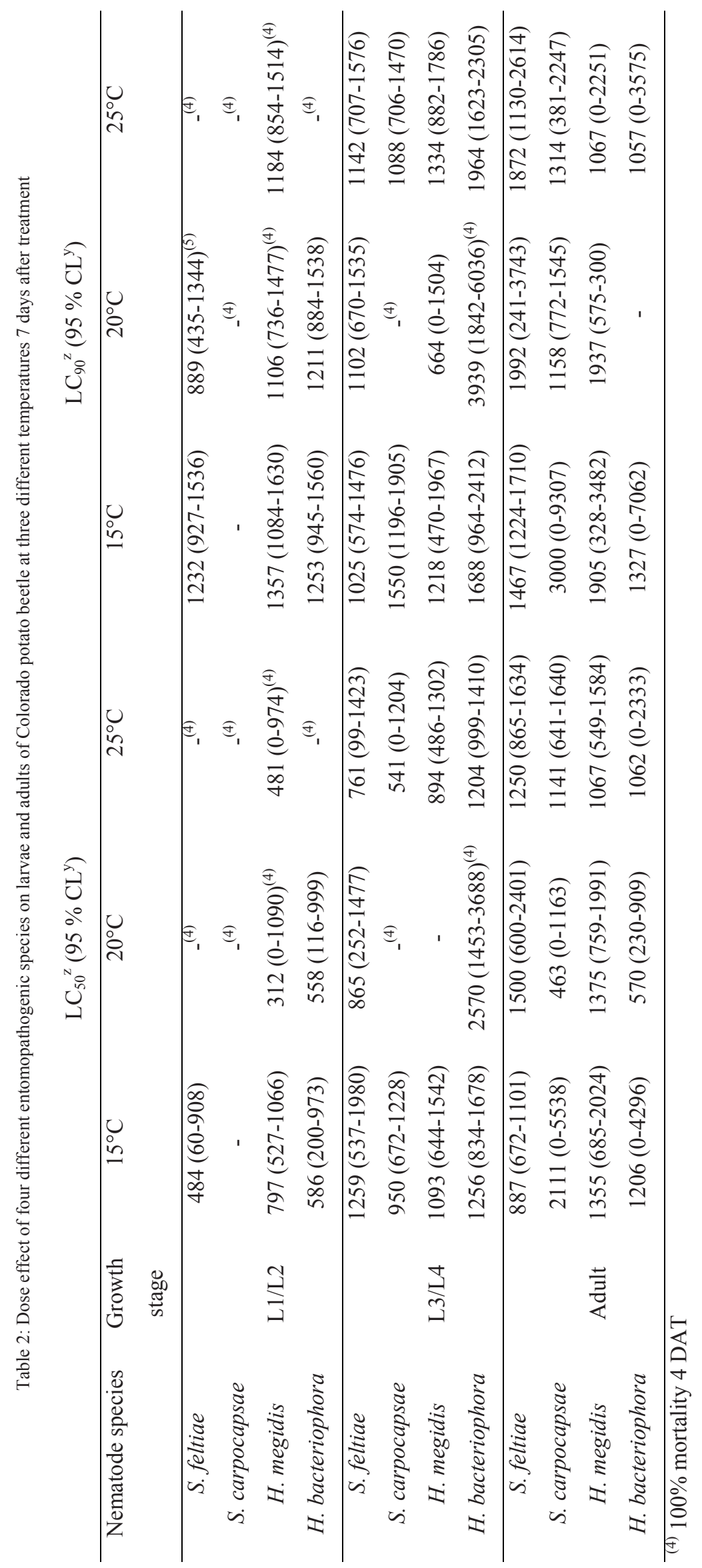




\section{Discussion}

The results of the present research indicate that both the temperature and the developmental stage of the Colorado potato beetle have an important influence on the efficacy of the EPNs as pest-control agents. At $15{ }^{\circ} \mathrm{C}$, a lower mortality was recorded than at 20 or $25^{\circ} \mathrm{C}$, thus supporting the results of our previous research (Trdan et al., 2006) and research from other groups (Kaya et al., 1993; Doucet et al., 1996; Choo et al., 2002; Belair et al., 2003; Yang et al., 2003). Controlling insect pests with a foliar application is becoming a more widely-used practice (Broadbent \& Olthof, 1995). If this method is required for the control of the first (overwintered) adults of the Colorado potato beetle, application of $S$. feltiae suspension in higher concentrations is recommended as our research demonstrated that this species showed the highest efficacy in controlling adults at $15{ }^{\circ} \mathrm{C}$. The first adults usually appear in the second half of May when the nights are still relatively fresh in the area in which our research took place. The early application of EPNs is a necessity as the excrements of Colorado potato beetle repel these biological agents (Thurston et al., 1994). Thus the rapid application of nematodes at higher concentrations not only provides a larger number of nematodes entering exposed individuals but also limits the repellent action of this insect pest on nematodes. At higher environmental temperatures of 20 and $25^{\circ} \mathrm{C}$, the best control of adults was obtained with $S$. carpocapsae; therefore we recommend this particular EPN in the control of the first adult generation (i.e. the offspring of overwintered adults). Control of adult chrysomelids with EPNs has not proven to be particularly successful until now. We assert this on the basis of research on Diabrotica virgifera virgifera LeConte (Toepfer et al., 2005) and Colaphellus bowringi Baly (Wei et al., 2000). The conclusion is also supported in part by our own data here, with adult beetles proving to be much more resistant to nematode infection than their larval counterparts.

At the lowest temperature of $15{ }^{\circ} \mathrm{C}$, the youngest larvae were the most susceptible to nematode infection. In fact, the youngest larvae were the most susceptible at all three temperatures assessed. From this point of view, old larvae are a somewhat less effective target for EPN treatment, but nevertheless still much more susceptible than adults. It is known that EPNs are more efficient against larvae and other pre-imaginal stages of insects because they can enter their body more easily (LeBeck et al., 1993). From this knowledge in combination with our present data, we might expect that the most effective EPN control would be seen in young larvae following a summer night application. In conditions of warm (above $20{ }^{\circ} \mathrm{C}$ ) and humid nights, a high percentage of mortality of young larvae would be expected after just two days following application of the biological agents.

Our current aim is to repeat the present research in field conditions as soon as possible. Now, when the use of $S$. feltiae and $S$. carpocapsae is allowed - namely, they recently become an indigenous species in our country (Laznik et al., 2008ab) - there are no legal obstacles for building the field experiment with these biological control agents. But it is also important to note that results from laboratory tests are not always comparable with field testing (Cantelo \& Nickle, 1992) as functioning of EPNs in the open is influenced by an extensive list of factors. In one relevant study, the $100 \%$ efficacy rate of $S$. carpocapsae in controlling Colorado potato beetle adults, pupae and larvae in the laboratory manifested in only a $31 \%$ reduction rate of the pest population when the test was repeated outdoors (Stewart et al., 1998) and a supporting dose of fenvalerate was considered. Some further results from studies of the activity of EPNs on related (Yang et al., 2003) and others species of beetles (Labanowska et al., 2004) have also shown that these agents could be an effective alternative to insecticides. It is our hope that these promising studies can soon be extended to outdoor tests of foliar applications of EPNs as a control method for the Colorado potato beetle and that these studies will further demonstrate these biological agents to be a practical and effective alternative to currently used methods for the control of this important agricultural pest.

\section{Acknowledgements}

This work was done within Horticulture No P4-0013-0481, a programme funded by the Slovenian Research Agency, and within L4-6477 and V4-0524, the programmes funded by the Slovenian Research Agency and the Ministry of Agriculture, Forestry and Food of Republic Slovenia. Tjaša Gril and Nevenka Valič are acknowledged for providing technical support.

\section{References}

Abbas, M. S. T., SAleh, M. M. E., AKIL, A. M. (2001): Laboratory and field evaluation of the pathogenicity of entomopathogenic nematodes to the red palm weevil, Rhynchophorus ferrugineus (Oliv.) (Col.: Curculionidae). Anz. Schädkdl., 74: $167-168$

Аввотт, W. S. (1925): A method of computing the effectiveness of an insecticide. J. Econ. Entomol. 18: 265 - 267 Arthurs S., HeInZ K. M., PrasifKA J. R. (2004): An analysis of using entomopathogenic nematodes against above-ground pests. Bull. Entomol. Res. 94: 297 - 306 Athanassiou, C. G., Kavallieratos, N. G., Dimizas, C. B., VAYiAS, B. J., TOMANOVIĆ Ž. (2006): Factors affecting the insecticidal efficacy of the diatomaceous earth formulation SilicoSec $®$ against adults of the rice weevil, Sitophilus oryzae (L.) (Coleoptera: Curculionidae). Appl. Entomol. Zool. 41: $201-207$

BElAir, G., FOURNIER, Y., DAUPhINAIS, N. (2003): Efficacy of steinernematid nematodes against three insect pests of crucifers in Quebec. J. Nematol. 35: $259-265$

Broadbent, A. B., Olthof, T. H. A. (1995): Foliar application of Steinernema carpocapsae (Rhabitida: Steinernematidae) to control Liriomyza trifolii (Diptera: Agromyzidae) larvae in chrysanthemums. Environ. 
Entomol., 24: $431-435$

CAntelo, W. W., Nickle, W. R. (1992): Susceptibility of prepupae of the Colorado potato beetle (Coleoptera: Chrysomelidae) to entomopathogenic nematodes (Rhabditida: Steinernematidae, Heterorhabditidae). J. Entomol. Sci., 27: $37-43$

Choo, H. Y., Lee, D. W., Yoon, H. S., Lee, S. M., Hang, D. T. (2002): Effects of temperature and nematode concentration on pathogenicity and reproduction of entomopathogenic nematode, Steinernema carpocapsae Pocheon strain (Nematoda: Steinernematidae). Korean J. Appl. Entomol., 41: $269-277$

Dolinski, C., Del Valle, E., Stuart, R. J. (2006): Virulence of entomopathogenic nematodes to larvae of the guava weevil, Conotrachelus psidii (Coleoptera: Curculionidae), in laboratory and greenhouses experiments. Biol. Control, 38: 422 - 427

Doucet, M. M. A., De Miranda, M. B., Bertolotti, M. A., CARO, K. A. (1996): Efficacy of Heterorhabditis bacteriophora (strain OLI) in relation to temperature, concentration and origin of the infective juvenile. Nematropica, 26: $129-133$

IGRC-BARČIĆ, J., DOBRINČIĆ, R., MACELJSKI, M. (1999): Effect of insecticides on the Colorado potato beetles resistant to OP, OC and P insecticides. Anz. Schädlkd., 72: $76-80$

Kaya, H. K., Burlando, T. M., Thurston, G. S. (1993): Two entomopathogenic nematode species with different search strategies for insect suppression. Environ. Entomol., 22: $859-864$

Kreutz, J., VAupel, O., ZimmermanN, G. (2004): Efficacy of Beauveria bassiana (Bals.) Vuill. against the spruce bark beetle, Ips typographus L., in the laboratory under various conditions. J. Appl. Entomol., 128: 384 - 389

Łabanowska, B. H., Olszak, R., Tkaczuk, C., AugusTYNIUK-KRAM, A. (2004): Efficacy of chemical and biological control of the strawberry root weevil (Otiorhynchus ovatus L.) and the vine weevil (Otiorhynchus sulcatus F.) in strawberry plantations in Poland. Bull. OILB/SROP 27: $153-159$

Lacey, L. A., Bettencourt, R., Garrett, F. J., Simoes, N. J. \& GAUGLER, R. H. (1993): Factors influencing parasitism of adult Japanese beetles, Popillia japonica (Col.: Scarabaeidae) by entomopathogenic nematodes. Entomophaga 38: $501-509$

LAZniK, Ž., Tóth, T., LAKatos, T., Trdan, S. (2008a) Entomopathogenic nematode Steinernema feltiae (Filipjev) (Rhabditida: Steinernematidae) recorded for the first time in Slovenia. Acta Agric. Slov. 91: $37-45$

LAZnik, Ž., TÓTH, T., LAKATOS, T., TRDAN, S. (2008b) Entomopathogenic nematode Steinernema carpocapsae (Weiser) (Rhabditida:Steinernematidae), a new member of Slovenian fauna. Acta Agric. Slov. 91: 351 - 359

LeBeck, L. M., Gaugler, R., Kaya, H. K., Hara, A. H., JOHNSON, M. W. (1993): Host stage suitability of the leafminer Liriomyza trifolii (Diptera: Agromyzidae) to the entomopathogenic nematode Steinernema carpocapsae (Rhabditida: Steinernematidae). J. Invertebr. Pathol., 62: 58 - 63
LIPA, J. J., SosnowsKA, D., Pruszynski, S. 2008. Advances in biological control of Leptinotarsa decemlineata in Poland. Bull. OEPP/EPPO Bull., 28: 463 - 469

Loseva, O., Ibrahim, M., Candas, M., Koller, C. N., BAUER, L. S., BULLA, L. A. JR. (2002): Changes in protease activity and Cry3Aa toxin binding in the Colorado potato beetle: implications for insect resistance to Bacillus thuringiensis toxins. Insect Biochem. Mol. Biol., 32: 567 - 577

OEPP/EPPO (1997): Leptinotarsa decemlineata. In: Smith et al. (eds.) Quarantine pests for Europe. Second Edition. Data sheets on quarantine pests for the European Union and for the European and Mediterranea Plant Protection Organization. CABI and EPPO, Wallingford, New York, $352-357$

PAP, L., Toth, A., KARIKAS, S. (1997): A survey of the insecticide resistance status of the Colorado potato beetle, Leptinotarsa decemlineata, in Hungary between 1987 and 1991. Pestic. Sci., 49: $389-392$

PrishchePA, L., MiKulskayA, N., BezRUChIONOK, N. (2000): Study of biological diversity of entomopathogenic nematodes in Belarus. Vestsi Akad. Agrar. Navuk Resp. Belarus' 2, 59 - 62 [in Russian]

PRUSZYNSKI, S., WEGOREK, P. (2004): Strategy for managing Colorado potato beetle (Leptinotarsa decemlineata Say) resistance in Poland. Progress Plant Prot., 44: 292 - 299 [in Polish]

ROSA, J. S., SIMÕES, N. (2004): Evaluation of twenty-eight strains of Heterorhabditis bacteriophora isolated in Azores for biocontrol of the armyworm, Pseudaletia unipuncta (Lepidoptera: Noctuidae). Biol. Control, 29: 409 - 417

SARINGER, G., Fodor, A., NADASY, M., LUCSKAI, A., GEORGIS, R. (1996): Possibilities of biological control using entomopathogenic nematodes against Leptinotarsa decemlineata L. and Athalia rosae L. larvae. Meded. Fac. Landbouwkd. Toegep. Biol. Wet. Univ. Gent, 61: 961 - 966 SERYCZYNSKA H., KAMIONEK M. (1974): Defensive reactions of Leptinotarsa decemlineata Say in relation to Neoaplectana carpocapsae Weiser (Nematoda: Steinernematidae) and Pristionychus uniformis Fedorko et Stanuszek (Nematoda: Diplogasteridae). Bull. l'Acad. Pol. Sci., 22: 95 - 100

SHAPIRO, D. I., McCoY, C. W. (2000): Virulence of entomopathogenic nematodes to Diaprepes abbreviatus (Coleoptera: Curculionidae) in the laboratory. J. Econ. Entomol., 93: 1090 - 1095

SIMSER, D. (1992): Field application of entomopathogenic nematodes for control of Delia radicum in collards. $J$. Nematol., 24: $374-378$

Stanković, S., Zabel, A., Kostić, M., Manojlović, B., RAJKOVIĆ, S. (2004): Colorado potato beetle [Leptinotarsa decemlineta (Say)] resistance to organophosphates and carbamates in Serbia. J. Pest Sci., 77: $11-16$

Stewart, J. G., Boiteau, G., Kimpinski, J. (1998): Management of late-season adults of the Colorado potato beetle (Coleoptera: Chrysomelidae) with entomopathogenic nematodes. Can. Entomol., 130: 509 - 514

SUSURLUK, I. A. (2008): Effects of various agricultural practices on persistence of the inundative applied 
entomopathogenic nematodes, Heterorhabditis bacteriophora and Steinernema feltiae in the field. Russ. J. Nematol. $16: 23-32$

Svendsen, T. S. \& SteEnBerG, T. 2000. The potential use of entomopathogenic nematodes against Typhaea stercorea. Biocontrol, 45, $97-111$

Thurston, G. S., Yule, W. N., Dunphy, G. B. (1994): Explanations for the low susceptibility of Leptinotarsa decemlineata to Steinernema carpocapsae. Biol. Control, 4: $53-58$

Toepfer, S., Gueldenzoph, C., Ehlers, R. U., KuHlMANN, U. (2005): Screening of entomopathogenic nematodes for virulence against the invasive western corn rootworm, Diabrotica virgifera virgifera (Coleoptera: Chrysomelidae) in Europe. Bull. Entomol. Res., 95: 473 - 482

TRDAN, S., VidRIH, M., VALIČ, N. (2006): Activity of four entomopathogenic nematode species against young adults of Sitophilus granarius (Coleoptera: Curculionidae) and Oryzaephilus surinamensis (Coleoptera: Silvanidae) under laboratory conditions. J. Plant Dis. Prot., 113: 168 - 173

RECEIVED NOVEMBER 13, 2007
Trdan, S., Vidrih, M., VALIČ, N., LAZNiK, Ž. (2008): Impact of entomopathogenic nematodes on adults of Phyllotreta spp. (Coleoptera: Chrysomelidae) under laboratory conditions. Acta Agric. Scand. Sect. B - Soil Plant Sci., 58: $169-175$

Wie, H. Y., Li, F., WAN, L., Ling, K. J., WU, D. L., ZHAO, F. X. (2000): Sensitivity of entomopathogenic nematode, Steinernema carpocapsae to vegetable beetle, Colaphellus bowringi Baly. Acta Agric. Univ. Jiangxiensi, 22: $243-$ 245 [in Chinese]

YANG, X., JiAn, H., LiU, Z., YanG, H., Yuan, J., QuAnli, Z., ShuANGyUe, L. (2003): Evaluation of entomopathogenic nematodes for control of the beetle, Luperomorpha suturalis Chen (Col., Chrysomelidae). J. Appl. Entomol., 127: $377-382$

Zehnder, G., Vencill, A. M., Speese, J. III. (1995): Action thresholds based on plant defoliation for management of Colorado potato beetle (Coleoptera: Chrysomelidae) in potato. J. Econ. Entomol., 88: 155 - 161

ACCEPTED NOVEMBER 24, 2008 